\title{
Pengungkapan Kompensasi Manajemen Kunci Dan Faktor-Faktor Yang Mempengaruhinya
}

\author{
Oh Joffina Gunawan \\ Universitas Katolik Soegijapranata \\ joffinagnwn@yahoo.com
}

\begin{abstract}
Abstrak
Informasi tentang jumlah kompensasi manajemen kunci bermanfaat bagi investor untuk menilai apakah pengelolaan sumber daya telah dilakukan secara bertanggung jawab dengan mempertimbangkan kontribusi manajemen kunci kepada perusahaaan. Pengungkapan gaji dan kompensaasi yang tidak transparan dapat merugikan investor karena pembayaran kompensasi yang berlebihan dapat menguras arus kas perusahaan dan akhirnya mempengaruhi kinerja keuangan. Karena itu perlu diketahui faktor-faktor apa yang mendorong perusahaan untuk mengungkapkan atau tidak mengunkapkan kompensasi manajemen kunci. Secara spesfiik, penelitian ini menguji lima variabel yang diduga mempengaruhi luas pengungkapan manajemen kunci yaitu transparansi tata kelola perusahaan, kualitas audit, kepemilikan keluarga, Komite Audit, dan Komite Remunerasi. Sampel perusahaan diambil dari perusahaan yang terdaftar di Bursa Efek Indonesia (BEI) periode tahun 2013-2017. Hasil analisis regresi menunjukkan bahwa transparansi tata kelola perusahaan, kepemilikan keluarga, Komite Audit berpengaruh positif terhadap luas pengungkapan kompensasi manajemen kunci. Sementara kualitas audit tidak berpengaruh terhadap luas pengungkapan kompensasi manajemen kunci. Komite remunerasi berpengaruh negatif terhadap luas pengungkapan kompensasi manajemen kunci.
\end{abstract}

\section{Kata Kunci : Tata Kelola Perusahaan, Kepemilikian Keluarga, Manajemen Kunci, Komite Remunerasi}

\begin{abstract}
Information about the amount of key management compensation paid by companies is useful for investors to assess effective use of firm resources. A non-transparent disclosure of compensation to key management can be detrimental to investors because excessive compensation payments can drain a company's cash flow and ultimately affect financial performance. Therefore, it is necessary to know what factors drive companies to disclose or not disclose key management compensation. Specifically, this study examines five variables that are thought to influence the extent of key management disclosures namely corporate governance transparency, audit quality, family ownership, the Audit Committee, and the Remuneration Committee. Company samples were taken from companies listed on the Indonesia Stock Exchange (IDX) for the period 2013-2017. Results show that transparency of corporate governance, family ownership, and the Audit Committee had a positive effect on the extent of disclosure of key management compensation. Audit quality does not affect the extent of disclosure of key management compensation. On the other hand, remuneration committee has a negative effect on the extent of disclosure of key management compensation.
\end{abstract}

\section{Key words : Corporate Governance, Family Ownership, Key Management, Remuneration committee.}




\section{PENDAHULUAN}

Personil manajemen kunci perusahaan adalah orang-orang yang mempunyai kewenangan dan tanggung jawab untuk merencanakan, memimpin dan mengendalikan aktivitas perusahaan, secara langsung maupun tidak langsung, termasuk seluruh anggota Dewan Komisaris dan Direksi perusahaan (Zhang dan Zhou, 2007). Personil manajemen kunci perusahaan merupakan manajemen perusahaan yang berada dalam jajaran Top Management. Selain karena merupakan pengungkapan wajib, pengungkapan kompensasi manajemen kunci di Laporan Keuangan dianggap penting karena dapat merepresentasikan pencapaian kinerja suatu perusahaan. Hal ini didukung oleh penelitian Conyon dan He (2011) yang menemukan hubungan positif antara kompensasi eksekutif dengan kinerja perusahaan.

Para pihak eksternal dapat menilai kinerja suatu perusahaan, salah satunya dengan melihat jumlah kompensasi manajemen kunci di Laporan Keuangan. Hal tersebut dikarenakan pembayaran kompensasi bagi manajemen kunci ditetapkan berdasarkan tingkat kinerja yang dicapai manajemen kunci dalam memenuhi target perusahaan. Sehingga dapat disimpulkan, semakin besar kompensasi yang diberikan kepada manajemen kunci dapat mengindikasikan semakin tinggi pula tingkat pencapaian kinerja manajemen kunci dalam rangka meningkatkan nilai perusahaan.

Kompensasi diberikan sebagai penyeimbang atas kesempatan yang hilang (opportunity loss) dari eksekutif tersebut. Namun pembayaran kompensasi kepada personil manajemen kunci sebagai salah satu transaksi pihak berelasi memiliki dampak potensi timbulnya moral hazard. Sehingga mengakibatkan konflik keagenan. Konflik keagenan memungkinkan manajemen sebagai pihak yang memahami bisnis perusahaan untuk memberikan informasi yang bersifat oportunis untuk kepentingan pribadinya sehingga tidak memberikan informasi yang luas kepada pemegang saham (Bhattacharya dan Spiegel, 1991).

Pengungkapan kompensasi manajemen kunci atau pengungkapan informasi yang kurang memadai dapat merugikan pengguna laporan. Informasi yang kurang memadai salah satunya dapat menyebabkan keputusan investasi yang salah bagi investor, oleh karena itu perlu diketahui faktor-faktor yang mempengaruhinya. Penelitian ini bertujuan untuk menguji faktorfaktor yang mempengaruhi luasnya pengungkapan kompensasi manajemen kunci dalam laporan keuangan (Nuryaman, 2009).

Penelitian yang dilakukan Akmyga dan Mita (2015) menunjukan bahwa kualitas audit berpengaruh terhadap luas pengungkapan kompensasi manajemen kunci. Semakin baik kualitas audit maka akan semakin luas pengungkapan kompensasi manajemen kunci (Akmyga dan Mita, 2015).

Akmyga dan Mita (2015) menemukan bahwa kepemilikan keluarga berpengaruh terhadap luas pengungkapan kompensasi manajemen kunci. Semakin tinggi prosentase kepemilikan keluarga berarti proses monitoring semakin baik sehingga akan berdampak pada luas pengungkapan kompensasi manajemen kunci. Anderson dan Reeb (2003) menyatakan bahwa pemegang saham pengendali dapat menempatkan anggota keluarganya di dalam manajemen perusahaan tersebut. Kondisi ini dapat mengakibatkan perbedaan luasnya informasi dan pemahaman bisnis antara pemegang saham pengendali dengan non-pengendali karena pemegang saham pengendali memiliki akses langsungkepada perusahaan. Ananda (2016) memberikan bukti pengaruh kepemilikan keluarga terhadap luas pengungkapan manajemen kunci dalam laporan tahunan.

Efektivitas komite audit sebagai salah satu mekanisme CG juga dapat memengaruhi luas pengungkapan kompensasi manajemen kunci. Zhang et al. (2007) menemukan bahwa perusahaan dengan komite audit yang tidak berjalan efektif dapat mengakibatkan lemahnya praktik internal control perusahaan sehingga memungkinkan manajemen untuk tidak memberikan informasi yang transparan kepada pemegang saham. Utama (2004) menyatakan bahwa komite audit yang dapat menjalankan fungsinya dengan efektif dapat mendorong 
perusahaan untuk memberikan informasi terkait pengungkapan keuangan perusahaan dengan lebih baik. Salah satunya yaitu pengungkapan kompensasi manajemen kunci.

Keberadaan komite remunerasi juga memungkinkan adanya proses monitoring yang semakin baik, yang berdampak pada semakin luasnya pengungkapan kompensasi manajemen kunci di laporan keuangan. Penelitian Mareysa (2019) menunjukan bahwa ada pengaruh komite remunerasi terhadap terhadap luas pengungkapan kompensasi manajemen kunci. Jadi dengan keberadaan komite remunerasi akan berpengaruh pada luas pengungkapan kompensasi manajemen kunci (Mareysa, 2019).

Penelitian Suherman (2019) menguji pengaruh kepemilikan keluarga efektivitas terhadap luas pengungkapan kompensasi manajemen kunci di laporan keuangan. Hasil penelitian menunjukan bahwa kepemilikan keluarga mempengaruhi luas pengungkapan kompensasi manajemen kunci. Sedangkan efektivitas komite audit, kualitas audit, leverage, dan profitabilitas tidak mempengaruhi luas pengungkapan. Mareysa (2019) menggunakan variabel kontrol ukuran perusahaan dengan hasil signifikan.

Penelitian ini menguji kembali faktor-faktor yang mempengaruhi luas pengungkapan kompensasi manajemen kunci dengan menambah satu variabel baru yaitu transparansi tata kelola perusahaan yang diukur dengan menggunakan indeks tata kelola dari ASEAN CGC Transparancy Index, serta menggunakan variabel kontrol ukuran perusahaan, leverage dan profitabilitas. Jika perusahaan semakin transparan dalam pengelolaan perusahaan maka akan berusaha untuk mengungkapkan tata kelola perusahaannya, termasuk dalam pengungkapan kompensasi manajemen kunci.

\section{Kerangka Pikir}

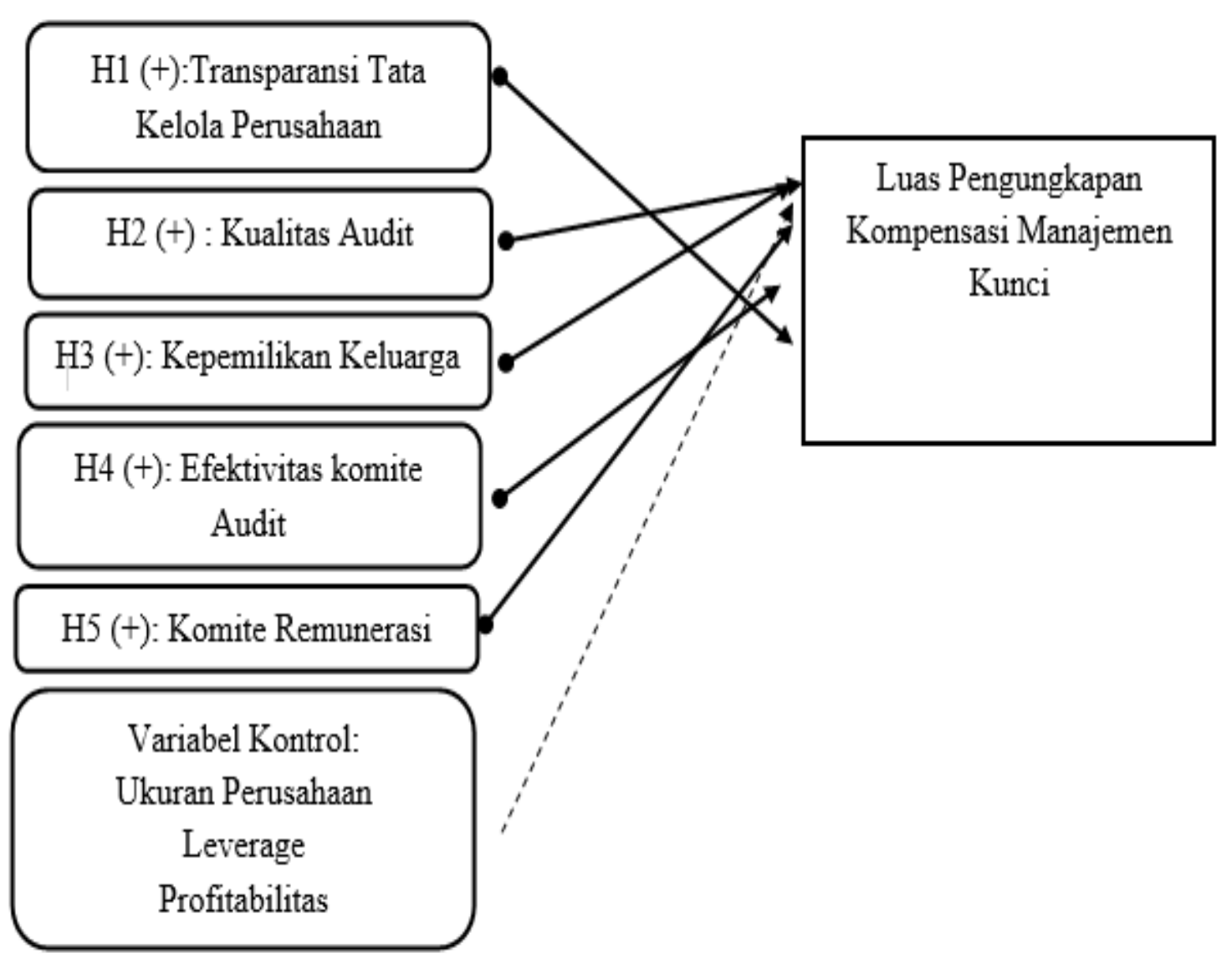




\section{TINJAUAN LITERATUR DAN PERUMUSAN HIPOTESIS}

\section{Tata Kelola Perusahaan}

Tata kelola adalah sistem yang dipergunakan untuk mengarahkan dan mengendalikan kegiatan bisnis perusahaan. Tata kelola mengatur pembagian tugas, hak, dan kewajiban pihakpihak dalam organisasi terhadap kehidupan perusahaan, termasuk para pemegang saham, dewan pengurus, para manajer dan semua anggota stakeholders non-pemegang saham. Pembagian tugas, hak, dan kewajiban juga berfungsi sebagai pedoman pengevaluasian kinerja Board of Directors dan manajemen perusahaan.

Corporate governance muncul karena terjadi pemisahan antara kepemilikan dengan pengendalian perusahaan, atau seringkali dikenal dengan istilah masalah keagenan. Permasalahan keagenan dalam hubungannya antara pemilik modal dengan manajer adalah bagaimana sulitnya pemilik dalam memastikan bahwa dana yang ditanamkan tidak diambil alih atau diinvestasikan pada proyek yang tidak menguntungkan sehingga tidak mendatangkan return. Corporate governance diperlukan untuk mengurangi permasalahan keagenan antara pemilik dan manajer (Conyon, 2011). Corporate Governance adalah rangkaian proses terstruktur yang digunakan untuk mengelola serta mengarahkan atau memimpin bisnis dan usahausaha korporasi dengan tujuan untuk meningkatkan nilai-nilai perusahaan serta kontinuitas usaha. Terdapat beberapa pemahaman tentang pengertian Corporate Governance yang dikeluarkan beberapa pihak baik dalam perspektif yang sempit (shareholder) dan perspektif yang luas (stakeholders, namun pada umumnya menuju suatu maksud dan pengertian yang sama.

Tujuan utama dari pengelolaan perusahaan yang baik adalah untuk memberikan perlindungan yang memadai dan memperlakukan pemegang saham dan pihak yang berkepentingan lainnya secara adil. Pedoman umum GCG dari KNKG menyatakan GCG diperlukan dalam rangka:

a. Mendorong tercapainya kesinambungan perusahaan melalui pengelolaan yang didasarkan pada prinsip transparansi, akuntabilitas, responsibilitas, independensi, serta kesetaraan dan kewajaran,

b. Mendorong pemberdayaan fungsi dan kemandirian masing - masing organ perusahaan, yaitu Dewan Komisaris, Direksi, dan Rapat Umum Pemegang Saham,

c. Mendorong pemegang saham, anggota dewan komisaris, dan anggota direksi agar dalam membuat keputusan dan menjalankan tindakannya dilandasi oleh nilai moral yang tinggi dan kepatuhan terhadap peraturan perundang - undangan,

d. Mendorong timbulnya kesadaran dan tanggung jawab sosial perusahaan terhadap masyarakat dan kelestarian lingkungan terutama di sekitar perusahaan,

e. Mengoptimalkan nilai perusahaan bagi pemegang saham dengan tetap memperhatikan pemangku kepentingan lainnya,

f. Meningkatkan daya saing perusahaan secara nasional maupun internasional, sehingga meningkatkan kepercayaan pasar yang dapat mendorong arus investasi dan pertumbuhan ekonomi nasional yang berkesinambungan.

\section{Luas Pengungkapan Kompensasi Manajemen Kunci}

Pengungkapan disebut juga dengan dislosure. Kata disclosure berarti tidak menutupi atau tidak menyembunyikan (Chariri \& Ghozali 2007:377). Apabila dikaitkan dengan laporan keuangan, disclosure mengandung arti bahwa laporan 23 keuangan harus memberikan informasi dan penjelasan yang cukup mengenai hasil aktivitas suatu usaha. Dengan demikian, informasi tersebut harus lengkap, jelas dan dapat menggambarkan secara tepat mengenai kejadian-kejadian ekonomi yang berpengaruh terhadap hasil operasi unit usaha tersebut. 
Hendriksen (2002:429) mengatakan secara sederhana bahwa pengungkapan dapat diartikan sebagai pengeluaran informasi (the release of information). Para akuntan cenderung menggunakan istilah ini dalam batasan yang lebih sempit, yaitu pengeluaran informasi dalam laporan keuangan, umumnya laporan tahunan. Informasi yang diungkapkan harus berguna dan tidak membingungkan pemakai laporan keuangan dalam membantu pengambilan keputusan ekonomi. Di Indonesia, pedoman penyajian dan pengungkapan laporan keuangan oleh perusahaan publik ditetapkan oleh Ketua Bapepam dalam surat edaran Nomor: SE02/PM/2002. Pengungkapan informasi yang lebih transparan dapat menarik minat investor untuk menanamkan modalnya pada perusahaan Terdapat dua jenis pengungkapan, yaitu pengungkapan yang sifatnya wajib (mandatory disclosure) dan pengungkapan yang sifatnya sukarela (voluntary disclosure). Pengungkapan wajib 5 merupakan pengungkapan minimum yang disyaratkan oleh standar akuntansi yang berlaku dan memaksa perusahaan untuk mengungkapkannya di Laporan Keuangan. Sedangkan pengungkapan sukarela merupakan pengungkapan butir-butir yang dilakukan sukarela oleh perusahaan tanpa diharuskan oleh peraturan yang berlaku (Sari, 2013).

pengungkapan hubungan, transaksi dan saldo pihak-pihak berelasi, termasuk komitmen, dalam laporan keuangan konsolidasi dan laporan keuangan tersendiri entitas induk. Pihak-pihak berelasi adalah orang atau entitas yang terkait dengan entitas tertentu dalam menyiapkan laporan keuangannya. PSAK tersebut salah satunya mewajibkan perusahaan untuk mengungkapkan jumlah kompensasi personil manajemen kunci di Laporan Keuangan, berupa rincian sub jumlah per kategori imbalan kerja. Kompensasi yang dimaksud merupakan seluruh imbalan kerja (sebagaimana didefinisikan dalam PSAK 24 (revisi 2004) tentang Imbalan Kerja), termasuk imbalan kerja yang berlaku pada PSAK 53 tentang Akuntansi Pembayaran Berbasis Saham.

Personil manajemen kunci perusahaan adalah orang-orang yang mempunyai kewenangan dan tanggung jawab untuk merencanakan, memimpin dan mengendalikan aktivitas perusahaan, secara langsung maupun tidak langsung, termasuk seluruh anggota Dewan Komisaris dan Direksi perusahaan. Atau dapat dikatakan, personil manajemen kunci perusahaan merupakan manajemen perusahaan yang berada dalam jajaran Top Management. Selain karena merupakan pengungkapan wajib, pengungkapan kompensasi manajemen kunci di Laporan Keuangan dianggap penting karena dapat merepresentasikan pencapaian kinerja suatu perusahaan. Hal ini didukung oleh penelitian Conyon dan $\mathrm{He}$ (2011) yang menemukan hubungan positif antara kompensasi eksekutif dengan kinerja perusahaan. Dengan begitu, para pihak eksternal dapat menilai kinerja suatu perusahaan, salah satunya dengan melihat jumlah kompensasi manajemen kunci di Laporan Keuangan.

\section{Transparasi Tata Kelola Perusahaan}

Corporate Governance Perception Index (CGPI) merupakan hasil riset dan program pemeringkatan Corporate Governance perusahaan yang berada di Indonesia. Program CGPI diselenggarakan oleh Indonesian Institute for Corporate Governance (IICG) tiap tahun dari tahun 2001 hingga sekarang.

sebagai lembaga masyarakat yang independen mengundang partisipasi perusahaan dalam CGPI tetapi tidak mewajibkan perusahaan untuk ikut serta (voluntary). Sehingga, keikutsertaan ini sebuah pilihan (elektif) untuk perusahaan dengan mempertimbangkan kesiapan internal perusahaan (selektif) berdasarkan tema penilaian CGPI yang telah ditentukan oleh IICG (elektif). CGPI diikuti oleh perusahaan publik (Emiten), Badan Usaha Milik Negara (BUMN), Badan Usaha Milik Swasta (BUMS), Badan Usaha Milik Daerah (BUMD), dan Lembaga Bisnis Syariah.Program CGPI menggunakan 3 (tiga) ruang lingkup penerapan GCG 
1. Aspek kepatuhandari implementasi GCG merupakan pemenuhan dari berbagai permintaan akan hukum dan regulasi atau peraturan yang ditetapkan oleh pembuat kebijakan. Aspek ini memastikan bahwa semua perusahaan dalam operasi bisnis telah berjalan dengna lancar dan tidak memiliki konflik tentang peraturan yang diterapkan.

2. Aspek kesesuaian dari implementasi GCG adalah aspek kelayakan dari kebijakan operasi perusahaan yang berhubungan dengan norma, etika dan nilai kepercayaan.

3. Aspek kinerja dari implementasi GCG terkait dengan pemenuhan dan pencapaian dari perusahaan dalam memenuhi permintaan etika dan operasionalisasinya.

Program CGPI 2012-2015 menggunakan penilaian yang mencakup aspek-aspek penerapan GCG (komitmen, transparansi, akuntabilitas, responsibilitas, independensi, keadilan, kepemimpinan, strategi, etika dan aspek lainnya yang mendukung tema penilaian CGPI per tahunnya). Aspek penilaian CGPI 2016 dalam kerangka GCG meliputi struktur tata kelola, proses tata kelola, hasil tata kelola.

Dalam tahap fase evaluasi, partisipan CGPI harus mengisi 36 jenis dari dokumen yang dibutuhkan yang berkaitan dengan status perusahaan. Pada tahap ketiga, masing-masing partisipan seharusnya mempersiapkan tentang gambaran implementasi CG dan menyajikannya selama kunjungan perushaaan. Pada tahap akhir, yaitu observasi, dimana tim independen akan melakukan klarifikasi dan memastikan praktek CG. Observasi pada masing-masing perusahaan dilakukan melalui presentasi, peninjauan langsung dan diskusi dengan dewan komisaris, direksi dan manajemen, dan pihak terkait lainnya hasil dari peringkat program CGPI ini menggunakan peraturan assesment yang didasarkan pada peringkat skor yang diterima oleh pihak yang berhubungan. Hasil peringkat hasil dari program CGPI ini kemudian dikategorisasikan berdasarkan pada tingkat kualitas GCG.

\section{ASEAN Corporate Governance Scorecard}

Untuk menjaga objektivitas dan kemandirian metodologi, ACMF telah meminta para ahli tata kelola perusahaan di wilayah tersebut untuk mengembangkan Scorecard dan kriteria penilaian. Para ahli untuk inisiatif tersebut dipilih berdasarkan pengalaman mereka dalam inisiatif peringkat tata kelola perusahaan di negara mereka sendiri dan pengakuan mereka sebagai otoritas di bidang tata kelola perusahaan. Mereka direkomendasikan oleh regulator pasar modal di masing-masing negara. Para ahli, disetujui oleh ACMF, tidak memiliki kepentingan dalam PLC dan tidak terkait dengan regulator sekuritas. Pengembangan Scorecard dipandu oleh prinsip-prinsip berikut:

1. Scorecard harus mencerminkan prinsip-prinsip global dan praktik-praktik baik yang diakui secara internasional dalam tata kelola perusahaan yang berlaku untuk PLC dan dalam beberapa contoh dapat melebihi persyaratan dan standar yang direkomendasikan dalam undang-undang nasional.

2. Scorecard tidak boleh didasarkan pada denominator umum terendah tetapi harus bertujuan mendorong PLC untuk mengadopsi standar dan aspirasi yang lebih tinggi

3. Scorecard harus komprehensif dalam cakupan, menangkap elemen-elemen penting dari tata kelola perusahaan

4. Scorecard harus memungkinkan kesenjangan dalam praktik tata kelola perusahaan di antara PLC ASEAN untuk diidentifikasi dan menarik perhatian pada praktik tata kelola perusahaan yang baik

5. Scorecard harus universal dan mampu diterapkan ke pasar yang berbeda di ASEAN

6. Metodologi harus kuat untuk secara akurat menilai tata kelola perusahaan dari PLC melampaui kepatuhan minimum dan menandai kotak

7. Harus ada proses jaminan kualitas yang luas dan kuat untuk memastikan independensi dan reliabilitas penilaian 


\section{Kualitas Audit}

Kualitas dari jasa audit menurut DeAngelo (1981) didefinisikan sebagai kemungkinan berdasarkan penilaian pasar bahwa seorang auditor akan mampu untuk menemukan pelanggaran di dalam sistem akuntansi kliennya dan kemudian melaporkan pelanggaran tersebut. Probabilitas bahwa seorang auditor akan dapat menemukan sebuah pelanggaran bergantung pada kemampuan auditor tersebut dalam menggunakan teknologi, prosedur audit yang diterapkan pada proses audit, tingkat pengambilan sampel, dan sebagainya.

Istilah "kualitas audit" mempunyai arti yang berbeda-beda bagi setiap orang. Para pengguna laporan keuangan berpendapat bahwa kualitas audit yang dimaksud terjadi jika auditor dapat memberikan jaminan bahwa tidak ada salah saji yang material (no material misstatements) atau kecurangan (fraud) dalam laporan keuangan audite. Auditor sendiri memandang kualitas audit terjadi apabila mereka bekerja sesuai standar profesional yang ada, dapat menilai resiko bisnis audite dengan tujuan untuk meminimalisasi resiko litigasi, dapat meminimalisasi ketidakpuasan audite dan menjaga kerusakan reputasi auditor.

Wooten (2003) telah mengembangkan model kualitas audit dari membangun teori dan penelitian empiris yang ada. Model yang disajikan oleh Wooten dalam penelitian ini dijadikan sebagai indikator untuk kualitas audit, yaitu (1) deteksi salah saji, (2) kesesuaian dengan SPAP, (3) kepatuhan terhadap SOP, (4) risiko audit, (5) prinsip kehati-hatian, (6) proses pengendalian atas pekerjaan oleh supervisor, dan (7) perhatian yang diberikan oleh manajer atau partner.

Deis dan Groux (1992) melakukan penelitian tentang empat hal dianggap mempunyai hubungan dengan kualitas audit yaitu (1) lama waktu auditor telah melakukan pemeriksaan terhadap suatu perusahaan (tenure), semakin lama seorang auditor telah melakukan audit pada audite yang sama maka kualitas audit yang dihasilkan akan semakin rendah, (2) jumlah audite, semakin banyak jumlah audite maka kualitas audit akan semakin baik karena auditor dengan jumlah audite yang banyak akan berusaha menjaga reputasinya, (3) kesehatan keuangan audite, semakin sehat kondisi keuangan audite maka akan ada kecenderungan audite tersebut untuk menekan auditor agar tidak mengikuti standar, dan (4) review oleh pihak ketiga, kualitas sudit akan meningkat jika auditor tersebut mengetahui bahwa hasil pekerjaannya akan direview oleh pihak ketiga.

Menurut Watkins dkk. (2004) dalam Putri (2012), berikut adalah beberapa definisi kualitas audit menurut para ahli:

1. Kualitas audit merupakan kemungkinan bahwa auditor tidak akan memberikan opini wajar tanpa pengecualian bagi laporan keuangan yang mengandung kesalahan material.

2. Kualitas audit diukur dari ketepatan informasi yang dilaporkan oleh auditor.

3. Kualitas audit ditentukan dari kemampuan auditor dalam mengurangi bias serta meningkatkan kemurnian data-data akuntansi.

Istilah "kualitas audit" memiliki arti yang berbeda-beda menurut pandangan dari setiap orang. Menurut Putri (2012), para pengguna laporan keuangan mendefinisikan kualitas audit sebagai jaminan yang dapat diberikan oleh auditor bahwa tidak ada salah saji yang material atau kecurangan dalam laporan keuangan kliennya.

Ikatan Akuntan Indonesia (IAI) menyatakan bahwa audit yang dilakukan auditor dikatakan berkualitas, jika memenuhi standar auditing dan standar pengendalian mutu. Langkah-langkah yang dapat dilakukan untuk meningkatkan Kualitas Audit adalah:

1) Meningkatkan pendidikan profesionalnya

2) Mempertahankan Independensi dalam sikap mental

3) Dalam melaksanakan pekerjaan audit, menggunakan kemahiran profesionalnya dengan cermat dan seksama

4) Melakukan perencanaan pekerjaan audit dengan baik

5) Memahami struktur pengendalian intern klien dengan baik

6) Memperoleh bukti audit yang cukup dan kompeten 
7) Membuat laporan audit yang sesuai dengan kondisi klien atau sesuai dengan hasil temuan.

Kualitas audit dapat diartikan sebagai bagus tidaknya suatu pemeriksaan yang telah dilakukan oleh auditor. Berdasarkan Standar Profesional Akuntan Publik (SPAP) audit yang dilaksanakan auditor dikatakan berkualitas, jika memenuhi ketentuan atau standar pengauditan. Standar pengauditan mencakup mutu professional, auditor independen, pertimbangan (judgement) yang digunakan dalam pelaksanaan audit dan penyusunan laporan audit.

\section{Kepemilikan Keluarga}

Kepemilikan saham di negara berkembang sebagian besar dikontrol oleh kepemilikan keluarga, termasuk perusahaan di Indonesia (Arifin, 2003), yaitu perusahaan yang dimiliki secara mayoritas oleh keluarga tertentu atau kepemilikan sahamnya terkonsentrasi pada keluarga tertentu. Menurut Wang, (2006) keluarga berkeinginan untuk meneruskan usahanya untuk generasi berikutnya. Dalam rangka menjaga reputasi perusahaan, manajemen dituntut untuk memberikan informasi yang transparan dan berkualitas.

Claessens et al. (1999) menyebutkan bahwa perusahaan yang dikontrol oleh keluarga dapat mengakibatkan ekspropriasi terhadap pemegang saham minoritas. Menurut Faccio et al. (2001), ekspropriasi dapat lebih mudahdilakukan pada perusahaan yang dimiliki oleh keluarga yang berada dalam grup perusahaan terafiliasi karena dikendalikan oleh pemegang saham yang sama. Claessens et al. (2000) menemukan bahwa sebagian besar perusahaandi Asia, termasuk Indonesia, dikendalikan oleh keluarga dalam grup perusahaan terafiliasi berbentuk struktur piramida atau cross holding. Ekspropriasi akan semakin meningkat melalui struktur piramida dan cross holding karenastruktur tersebut memberi peluang semakin besarnya informasi asimetri.

Suatu perusahaan dapat dikatakan dimiliki oleh keluarga (family owned) jika keluarga tersebut merupakan controlling shareholders, atau mempunyai saham setidaknya $20 \%$ dari voting rights dan merupakan pemilik saham tertinggi dibandingkan dengan shareholders lainnya (Kamaliah , 2013:5). Perusahaan publik di Indonesia memiliki karakteristik yang tidak berbeda dengan perusahaan di Asia pada umumnya. Perusahaan-perusahaan di Asia secara historis dan sosiologis adalah perusahaanperusahaan uang dimiliki atau di kontrol oleh keluarga (Claessens, 1999:3). Meskipun perusahaan-perusahaan tersebut tumbuh dan menjadi perusahaan publik, namun kontrol tetap dipegang oleh keluarga dan masih begitu signifikan.

Pada awalnya, perusahaan keluarga merupakan perusahaan tertutup dan mendanai kegiatan usahanya dari modal sendiri dan didukung oleh pinjaman pihak luar. Namun seiring dengan perkembangan ekonomi dan pasar modal, banyak dari perusahaan yang dikategorikan sebagai family ownership ini kemudian menjadi perusahaan terbuka. Dengan menjadi perusahaan terbuka, maka rasio dan profit dari perusahaan menjadi terbagi dengan pihak luar. Selain itu, perusahaan juga dapat memperoleh lebih banyak dana dan melakukan ekspansi usahanya dengan menjadi perusahaan terbuka.

\section{Efektivitas Komite Audit}

Komite Audit bertugas membantu dewan komisaris dalam tugasnya. Komite audit bertugas untuk memberikan pendapat kepada Dewan Komisaris terhadap laporan atau hal-hal yang disampaikan oleh direksi kepada Dewan Komisaris (Bapepam Kep-305/BEJ/072004).Komite audit t mempunyai kemampuan untuk mengaitkan berbagai pihak yang ikut serta dalam proses pelaporan keuangan (Suaryana, 2005).

Menurut Arens et al $(2008,112)$, Komite Audit adalah sejumlah anggota dewan direksi perusahaan yang tanggung jawabnya termasuk membantu auditor agar tetap independen dari manajemen. Kebanyakan komite audit terdiri dari tiga hingga lima atau terkadang paling banyak tujuh direktur yang bukan merupakan bagian dari manajemen perusahaan. 
Pada umumnya dewan komisaris membentuk komite-komite dibawahnya sesuai dengan kebutuhan perusahaan dan peraturan perundangan yang berlaku untuk membantu dewan komisaris dalam melaksanakan tanggungjawab dan wewenangnya secara efektif. Komite yang dibentuk oleh dewan komisaris independen tersebut adalah komite audit, komite kebijakan risiko, komite remunerasi dan nominasi, komite kebijakan corporate governance (Komite Nasional Kebijakan Governance, 2006). Namun, menurut peraturan yang dikeluarkan oleh Bapepam No: KEP-339/BEJ/2001, yang sifatnya wajib dan harus dimiliki oleh perusahaan yang terdaftar di Bursa Efek hanya komite audit.Menurut Tugiman (1995), komite audit adalah sekelompok orang yang dipilih oleh kelompok yang lebih besar untuk mengerjakan pekerjaan tertentu atau untuk melakukan tugas-tugas khusus atau sejumlah anggota Dewan Komisaris perusahaan klien yang bertanggungjawab untuk membantu auditor dalam mempertahankan independensinya dari manajemen".

Komite audit dengan jumlah atau ukuran yang semakin banyak berarti ide akan lebih banyak dan kinerja lebih baik karena adanya kerja sama dari berbagai anggota dan ketua komite audit dalam pekerjaan lapangannya.Untuk mempertahankan independensi, Badan Pengawas Pasar Modal dan Laporan Keuangan (BAPEPAM-LK) (2004) mengeluarkan peraturan tentang Komite Audit yang menyebutkan bahwa komite audit paling kurang terdiri dari 3 (tiga) orang anggota yang berasal dari Komisaris Independen dan pihak dari luar Emiten atau perusahaan publik. Tujuan umum dari pembentukan komite audit, antara lain untuk mengembangkan kualitas pelaporan keuangan. Memastikan bahwa direksi membuat keputusan berdasarkan kebijakan, praktik dan pengungkapan akuntansi, menelaah ruang lingkup dan hasil dari audit internal dan eksternal, dan mengawasi proses pelaporan keuangan.

\section{Komite Remunerasi}

Perusahaan-perusahaan Indonesia pada masa ini memiliki kebutuhan untuk semakin meningkatkan kompetensi dan efektivitas dalam pencapaian visi misi perusahaan. Terkait hal tersebut, penerapan manajemen risiko korporasi terpadu atau Enterprise Risk management (ERM) semakin memperoleh perhatian. Penerapan ERM ini menjadi penting karena siklus bisnis yang penuh ketidakpastian dan dinamis menuntut perusahaan untuk lebih siap dan fleksibel dalam mengantisipasi setiap perubahan baik perubahan positif maupun negatif demi mencapai tujuan perusahaan. Manajemen risiko dalam perusahaan terhubung erat dengan praktik Good Corporate Governance (GCG) di perusahaan-perusahaan dan penerapan GCG ini diharapkan dapat menciptakan nilai perusahaan secara berkesinambungan melalui pola pertumbuhan yang sehat dalam jangka panjang. Terkait dengan GCG tersebut, Dekom (Dewan Komisaris) perusahaan membentuk Komite Audit, Komite Pemantau Risiko, serta Komite Nominasi dan Remunerasi untuk mendukung efektivitas pelaksanaan tugas dan tanggung jawab Dekom. Keberadaan masing-masing komite tersebut memiliki peran penting dalam manajemen perusahaan, namun penulisan kali ini akan berfokus pada Komite Nominasi dan Remunerasi.

\section{Pengembangan Hipotesis}

\section{Transparansi dan Kompensasi Manajemen Kunci}

Corporate Governance atau tata kelola perusahaan merupakan struktur dan mekanisme yang mengatur pengelolaan perusahaan sehingga menghasilkan nilai ekonomi jangka panjang yang berkesinambungan bagi para pemegang saham maupun pemangku kepentingan. Penerapan prinsip prinsip tata kelola perusahaan yang baik dapat berkontribusi dalam peningkatan kinerja perusahaan.Perusahaan yang memiliki good corporate governance yang baik berarti kinerjanya semakin baik (Sari, 2013).

Corporate governance muncul karena terjadi pemisahan antara kepemilikan dengan pengendalian perusahaan, atau seringkali dikenal dengan istilah masalah keagenan. 
Permasalahan keagenan dalam hubungannya antara pemilik modal dengan manajer adalah bagaimana sulitnya pemilik dalam memastikan bahwa dana yang ditanamkan tidak diambil alih atau diinvestasikan pada proyek yang tidak menguntungkan sehingga tidak mendatangkan return. Corporate governance diperlukan untuk mengurangi permasalahan keagenan antara pemilik dan manajer (Conyon, 2011). Corporate Governance adalah rangkaian proses terstruktur yang digunakan untuk mengelola serta mengarahkan atau memimpin bisnis dan usahausaha korporasi dengan tujuan untuk meningkatkan nilai-nilai perusahaan serta kontinuitas usaha. Maka berdasarkan uraian tersebut, hipotesisnya adalah:

\section{$\mathrm{H}_{1}$ : Transparansi tata kelola perusahaan berpengaruh positif terhadap luas pengungkapan kompensasi manajemen kunci di Laporan Keuangan}

\section{Kualitas audit dan Kompensasi Manajemen Kunci}

Kualitas audit menurut DeAngelo (1981) adalah kemungkinan bahwa seorang auditor akan mampu untuk menemukan pelanggaran di dalam sistem akuntansi kliennya dan kemudian melaporkan pelanggaran tersebut. Para pengguna laporan keuangan berpendapat bahwa kualitas audit yang dimaksud terjadi jika auditor dapat memberikan jaminan bahwa tidak ada salah saji yang material (no material misstatements) atau kecurangan (fraud) dalam laporan keuangan audite. Auditor sendiri memandang kualitas audit terjadi apabila mereka bekerja sesuai standar profesional yang ada, dapat menilai resiko bisnis audite dengan tujuan untuk meminimalisasi resiko litigasi, dapat meminimalisasi ketidakpuasan audit dan menjaga kerusakan reputasi auditor.

Auditor dalam mengaudit laporan keuangan memberikan usulan laporan keuangan supaya lebih transparan dan supaya pihak luar bisa menguji. Informasi mengenai penggunaan manajemen kunci dianggap sangat penting, karena informasi tersebut dibutuhkan bagi pihak luar untuk menilai perusahaan tersebut sudah dikelola dengan baik atau belum. Pengukuran kualitas audit dapat ditentukan melalui ukuran KAP yang melakukan audit di perusahaan tersebut. Perusahaan yang diaudit oleh KAP besar (KAP Big 4) diharapkan dapat mengungkapkan informasi keuangan dengan lebih luas karena KAP Big 4 memiliki insentif untuk melindungi reputasi KAP-nya sehingga dapat lebih transparan dan mendorong luasnya pengungkapan kompensasi manajemen kunci di laporan keuangan. Informasi mengenai pengungkapan kompensasi manajemen dianggap penting bagi pihak luar untuk menilai apakah perusahaan telah dikelola dengan baik, jangan sampai manajer menerima gaji yang lebih besar daripada yang seharusnya (Nielson dan Percy, 2004). Berdasarkan pada uraian tersebut maka hipotesisnya adalah:

\section{$\mathrm{H}_{2}$ : Kualitas audit berpengaruh positif terhadap luas pengungkapan kompensasi manajemen kunci di Laporan Keuangan.}

\section{Kepemilikan Keluarga dan Kompensasi Manajemen Kunci}

Kepemilikan keluarga yang tidak berada dalam grup perusahaanterafiliasi dipandang akan lebih fokus, berhati-hati, dan memiliki kepentingan jangka panjang dalam berinvenstasi karena tidak banyak ruang untuk melakukan ekspropriasi melalui transaksi antar afiliasi (Sembiring, 2005). Sedangkan pengungkapan sukarela merupakan pengungkapan butir-butir yang dilakukan sukarela oleh perusahaan tanpa diharuskan oleh peraturan yang berlaku (Sari, 2013). Oleh karena itu, riset ini menduga bahwa kendali keluarga yang berada pada satu perusahaan yang tidak terafiliasi dalam grup akan berpengaruh positif terhadap luasnya pengungkapan transaksi berelasi dilaporan keuangan, yang salah satunya adalah pengungkapan kompensasi manajemen kunci (Jensen dan Meckling, 1976).

Semakin tinggi prosentase kepemilikan keluarga, menunjukkan bahwa pengawasan atau monitoring dari pihak keluarga semakin baik dan ketat. Supaya pihak luar atau investor mengetahui kondisi atau kinerja perusahaan tersebut maka dibutuhkan sinyal positif ke pasar. 
Semakin besar prosentase kepemilikan keluarga mengindikasikan semakin baik pula tingkat pengawasan sehingga pencapaian kinerja perusahaan semakin baik dan dengan kinerja yang semakin baik maka manajemen kunci akan menuntut kompensasi yang memadai. Supaya pihak investor (luar) mengetahui kondisi perusahaan tersebut, maka pihak manajemen perusahaan akan terdorong untuk melakukan pengungkapan lebih luas dalam laporan keuangan perusahaan, termasuk dalam pengungkapan kompensasi manajemen kunci di Laporan Keuangan untuk semakin meyakinkan investor untuk melakukan investasi di suatu perusahaan. Dengan demikian dapat dikatakan adanya pengaruh positif antara kepemilikan keluarga terhadap luas pengungkapan kompensasi manajemen kunci di laporan keuangan. Berdasarkan pada uraian tersebut maka hipotesisnya adalah:

\section{H3: Kepemilikan keluarga berpengaruh positif terhadap luas pengungkapan kompensasi manajemen kunci di Laporan Keuangan}

\section{Komite Audit dan Kompensasi Manajemen Kunci}

Komite audit yang bertugas dengan efektif dapat mendorong internal control perusahaan menjadi lebih baik. Praktik internal control yang baik diharapkan dapat mendorong kepatuhan perusahaan untuk mematuhi standar akuntansi yang berlaku, salah satunya melalui pengungkapan kompensasi manajemen kunci di laporan keuangan (Wang, 2006).

Efektifitas pertemuan komite audit diukur dengan jumlah rapat komite audit yang ada dalam sebuah perusahaan dalam setahun. Semakin efektif komite audit berarti dalam menjalankan tugasnya semakin baik karena semakin banyak diskusi dilakukan dalam rapat tersebut dan ini akan meningkatkan proses monitoring. Tugas atau fungsi dari komite audit sebagai wakil dari Dewan Komisaris dan pemegang saham adalah melakukan evaluasi dan penelaahan Laporan Keuangan Perseroan secara periodik berdasarkan peraturan dan prinsipprinsip akuntansi yang berlaku, memberikan rekomendasi sehubungan dengan proses pengendalian internal. Apabila komite audit semakin sering melakukan rapat berarti akan semakin mendorong kerja dari pihak manajemen untuk melakukan pengungkapan atau meningkatkan transparansi termasuk dalam luas pengungkapan kompensasi manajemen kunci di laporan keuangan. Hal ini dilakukan untuk menarik minat investor untuk meningkatkan transparansi atau luas pengungkapan dalam laporan keuangan supaya manajemen kunci dibayar dengan layak atau memadai. Dengan demikian dapat dikatakan bahwa ada pengaruh positif antara efektivitas komite audit terhadap pengungkapan kompensasi manajemen kunci di laporan keuangan. Berdasarkan pada uraian tersebut maka hipotesisnya adalah:

\section{H4: Efektivitas komite auditberpengaruh positif terhadap luas pengungkapan kompensasi manajemen kunci di Laporan Keuangan}

\section{Komite Remunerasi dan Kompensasi Manajemen Kunci}

Komite remunerasi yang dibentuk oleh Dewan Komisaris juga termasuk perwakilan dari pemegang saham yang menginginkan seluruh informasi mengenai gaji atau kompensasi yang diterima oleh direksi diketahui oleh para pemegang saham agar pemegang saham dapat mengetahui laporan yang diungkapkan wajar atau tidak jumlah kompensasi manajemen kuncinya, jadi jika laporan mengenai kompensasi manajemen kunci dianggap tidak wajar akan ada tenaga penyesuaian agar laporan tentang pengungkapan kompensasi manajemen kunci yang disajikan lebih transparan (Dalton et al, 2011). Semakin banyak jumlah anggota komite remunerasi maka menunjukkan bahwa perusahaan memiliki implementasi tata kelola yang baik sehingga proses internal kontrol semakin baik pula termasuk dalam mengungkapkan informasi mengenai kompensasi manajemen kunci. Informasi tentang pengungkapan kompensasi manajemen kunci dianggap hal penting karena informasi tersebut dibutuhkan bagi pihak investor untuk menilai apakah perusahaan tersebut telah dikelola dengan baik. Hal ini juga dapat diketahui bahwa dengan adanya proses internal yang baik akan berdampak pada semakin 
patuhnya pihak manajemen perusahaan dalam mengungkapkan semakin tingginya luas pengungkapan kompensasi manajemen kunci pada laporan keuangan (Pukthuanthong et al, 2014). Dengan demikian hipotesisnya adalah:

\section{H5 : Komite remunerasi berpengaruh positif terhadap luas pengungkapan kompensasi manajemen kunci di Laporan Keuangan}

\section{METODE PENELITIAN}

\section{Populasi dan Sampel Penelitian}

Populasi dalam penelitian ini adalah semua perusahaan yang terdaftar di Bursa Efek Indonesia (BEI) selama tahun 2013-2017. Pemilihan sampel dalam populasi ini menggunakan metode purposive sampling dengan kriteria tertentu. Data sekunder dalam penelitian ini berupa laporan keuangan dari perusahaan yang terdaftar di BEI periode 2013-2017. Sumber data berasal dari IDX Statistik PIPM Semarang dan situs BEI (www.idx.co.id). Seleksi pemilihan sampel dapat dilihat pada tabel 1. Jumlah sampel perusahaan akhir yang tersedia untuk pengujian hipotesis adalah 1.799 observasi .

Tabel 1. Seleksi Pemilihan Sampel

\begin{tabular}{|l|l|l|l|l|l|l|}
\hline \multicolumn{1}{|c|}{ Keterangan } & 2013 & 2014 & 2015 & 2016 & 2017 & Jumlah \\
\hline $\begin{array}{l}\text { Perusahaan yang terdaftar di BEI tahun } \\
\text { 2013-2017. }\end{array}$ & 435 & 457 & 451 & 450 & 450 & 2243 \\
\hline $\begin{array}{l}\text { Laporan Tahunan yang tidak tersedia dari } \\
\text { sumber data yang digunakan }\end{array}$ & $(47)$ & $(56)$ & $(31)$ & $(59)$ & $(65)$ & $(258)$ \\
\hline $\begin{array}{l}\text { Perusahaan yang tidak memiliki frekuensi } \\
\text { rapat komite audit }\end{array}$ & $(23)$ & $(38)$ & $(31)$ & $(37)$ & $(77)$ & $(206)$ \\
\hline Total Sampel & 365 & 363 & 389 & 354 & 308 & 1799 \\
\hline
\end{tabular}

\section{Pengukuran Variabel}

\section{Luas Pengungkapan Kompensasi Manajemen Kunci}

Dalam penelitian ini, luas pengungkapan kompensasi manajemen kunci dilihat dari jumlah item yang diungkapkan perusahaan dalam laporan keuangan yang berkaitan dengan kompensasi manajemen kunci. Luas pengungkapan diukur dengan menggunakan skor seperti yang dilakukan Farahmita (2012). Skor pengungkapan terbagi lima :

a) Skor 0 diberikan apabila perusahaan tidak mengungkapkan kompensasi manajemen kunci di laporan keuangan.

b) Skor 1 diberikan apabila perusahaan hanya menyajikan total kompensasi tanpa keterangan kategori imbalan.

c) Skor 2 diberikan apabila perusahaan mengungkapkan total kompensasi masing-masing komisaris dan direktur.

d) Skor 3 diberikan apabila perusahaan mengungkapkan total kompensasi dengan memberikan deskripsi/kategori imbalan.

e) Skor 4 diberikan apabila perusahaan mengungkapkan total kompensasi dan memberikan rincian sub jumlah per kategori imbalan kerja.

\section{Transparansi Tata Kelola Perusahaan}


Transparansi Tata Kelola Perusahaan diukur menggunakan indeks transparansi berdasarkan Asean GCG Scorecard yang terdiri dari 42 item. Indeks transparansi masingmasing perusahaan dihitung dengan membandingkan jumlah item yang diungkapkan dalam laporan keuangan perusahaan dibagi dengan 42 seperti tertera dibawah ini:

Index Transparansi $=\underline{\text { Jumlah item yang diungkapkan }}$

42

\section{Kualitas Audit}

Kualitas audit diukur mengguakan variabel dummy yang bernilai 1 jika perusahaan diaudit KAP yang berafiliasi Big 4 dan 0 jika sebaliknya. Auditor yang termasuk dalam kelompok The Big 4 yaitu: 1. Deloitte Touche Tohmatsu (Deloitte) yang berafiliasi dengan Hans Tuanakotta Mustofa \& Halim; Osman Ramli Satrio \& Rekan; Osman Bing Satrio \& Rekan. 2. Ernest \& Young (EY) yang berafiliasi dengan Prasetio, Sarwoko \& Sandjaja Purwantono. 3. Klynveld Peat Marwick Goerdeler yang berafiliasi dengan Siddharta \& Widjaja.4. Pricewaterhouse Coopers $(\mathrm{PwC})$ yang berafiliasi dengan Haryanto Sahari \& Rekan.

\section{Kepemilikan keluarga}

Kepemilikan keluarga merupakan prosentase kepemilikan keluarga yang dimiliki oleh perusahaan publik yang terdaftar di BEI. Kepemilikan keluarga diukur dengan jumlah \% kepemilikan keluarga yang ada di dalam perusahaan.

\section{Efektifitas Komite Audit}

Efektivitas komite audit merupakan seberapa efektif komite audit bekerja yang dilihat dari jumlah rapat komite audit dalam sebuah perusahaan. Efektifitas pertemuan komite audit diukur dengan jumlah rapat komite audit yang ada dalam sebuah perusahaan dalam setahun.

\section{Komite remunerasi}

Komite remunerasi adalah komite dalam sebuah perusahaan yang mengatur tentang remunerasi dalam sebuah perusahaan. Komite remunerasi pada penelitian ini diukur dengan variabel dummy yaitu 0 jika perusahaan tidak memiliki komite remunerasi dan 1 jika perusahaan memiliki komite remunerasi.

\section{Model Regresi}

Untuk pengujian hipotesis penelitian maka digunakan analisis regresi linier berganda, karena penelitian ini bertujuan untuk mengetahui pengaruh lebih dari satu variabel independen terhadap satu variabel dependen. Model persamaan regresi dalam penelitian ini sebagai berikut:

$$
\begin{gathered}
\mathrm{LPL}=\beta_{0}+\beta_{1} \text { TRANSPARASI }+\beta_{2} \mathrm{KA}+\beta_{3} \mathrm{KK}+\beta_{4} \mathrm{EKA}+\beta_{5} \mathrm{KR}+ \\
\beta_{5} \mathrm{UK}+\beta_{6} \mathrm{LEV}+\beta_{7} \text { PROFIT }+\mathrm{e}
\end{gathered}
$$

Keterangan:

$\begin{array}{ll}\text { LPL } & =\text { Luas Pengungkapan Kompensasi Manajemen Kunci } \\ \beta_{0} & =\text { Konstanta } \\ \text { TRANSPARASI } & =\text { Indeks Pengungkapan Transparasi GCG } \\ \text { KA } & =\text { Kualitas Audit } \\ \text { KK } & =\text { Kepemilikan Keluarga } \\ \text { EKA } & =\text { Efektifitas Komite Audit } \\ \text { KR } & =\text { Komite Remunerasi } \\ \text { UK } & =\text { Ukuran perusahaan } \\ \text { LEV } & =\text { Leverage } \\ \text { PROFIT } & =\text { Profitabiltias }\end{array}$




\section{HASIL DAN PEMBAHASAN}

\section{Statistik Deskriptif}

Pada bagian ini akan dibahas mengenai statistik deskriptif pada penelitian ini. Dari data awal berjumlah 1779 , ternyata ada cukup banyak data yang tidak normal sehingga data normalnya berjumlah 747 .

Tabel 2.

Statistik Deskriptif

\begin{tabular}{|l|l|l|l|l|l|}
\hline & & Minimum & Maximum & Mean & $\begin{array}{l}\text { Std. } \\
\text { Deviation }\end{array}$ \\
\hline LPL & 747 & 1,00 & 4,00 & 1,17 & 0,45 \\
\hline TRANS & 747 & 0,33 & 0,88 & 0,61 & 0,10 \\
\hline KK & 747 & 0,00 & 34,64 & 0,62 & 3,42 \\
\hline EKA & 747 & 0,00 & 34,00 & 5,25 & 3,88 \\
\hline UK & 747 & 23,93 & 34,25 & 28,56 & 1,64 \\
\hline LEV & 747 & $-24,12$ & 18,19 & 1,51 & 2,85 \\
\hline PROFIT & 747 & $-9,11$ & 0,61 & 0,01 & 0,48 \\
\hline
\end{tabular}

Berdasarkan pada tabel di atas dapat diketahui transparasi tata kelola perusahaan (TRANS) memiliki nilai minimum 0,33, yaitu pada PT Bank QNB Indonesia Tbk (BKSW) Tahun 2015 nilai maksimum 0,88 yaitu pada PT Pelayaran Tempuran Emas Tbk (TMAS) Tahun 2015 dan rata-ratanya 0,61 dengan standard deviasi sebesar 0,10. Jadi berdasarkan nilai rata-rata 0,61 dapat dikatakan bahwa perusahaan cenderung mengungkapkan indeks tata kelola sebanyak $61 \%$ atau 26 item dari total 42 item transparansi tata kelola perusahaan. Artinya perusahaan cenderung tinggi melakukan pengungkapan transparansi tata kelola karena diatas $50 \%$.

Variabel kepemilikan keluarga (KK) memiliki nilai minimum sebesar 0,00 yaitu pada Perusahaan Gas Negara Tbk (PGAS) Tahun 2015 dan maksimum sebesar 34,64 yaitu pada perusahaan Logindo Samudramakmur (LEAD) Tahun 2015 dengan rata-ratanya sebesar 0,62 dan standar deviasi sebesar 3,42. Jadi berdasarkan nilai rata-rata 0,62 menunjukkan bahwa prosentase kepemilikan keluarga yang dimiliki oleh pihak keluarga adalah sebesar $0,62 \%$. Artinya mayoritas perusahaan pada penelitian ini dimiliki oleh kepemilikan keluarga $0,62 \%$ relatif kecil, tidak mencapai $1 \%$.

Untuk variabel efektivitas komite audit (EKA) rata-ratanya sebesar 5,25 nilai minimum 0,00 yaitu pada PT. Roda Vivatex Tbk (RDTX) Tahun 2013 dan maksimum sebesar 34,00 yaitu pada perusahaan PT. Telekomunikasi Indonesia Tbk (TLKM) Tahun 2015 dengan standar deviasi sebesar 3,88. Jadi jika dilihat dari nilai rata-ratanya sebesar 5,25 menunjukkan bahwa perusahaan sampel pada penelitian ini memiliki frekuensi pertemuan komite audit sekitar 5-6 kali pertemuan, artinya perusahaan sudah mematuhi dan sesuai dengan peraturan Bapepam dimana frekuensi minimum rapat komite audit adalah 5 kali dalam setahun.

Untuk variabel ukuran perusahaan (UK) rata-ratanya sebesar 28,56 nilai minimum 23,93 yaitu pada PT Akbar Indo Makmur Stimec Tbk (AIMS) Tahun 2013 dan maksimum sebesar 34,25 yaitu pada PT Bank Central Asia (BBCA) Tahun 2017 dengan standar deviasi sebesar 1,64. Jadi nilai rata-rata 28,56 menunjukkan bahwa perusahaan yg menjadi sampel penelitian ini rata-rata logaritma natural total aset perusahaan sebesar 28,56.

Untuk variabel leverage ( $L E V$ ) rata-ratanya sebesar 1,51, nilai minimum -24,12 yaitu pada PT. Bumi Resources Tbk (BUMI) Tahun 2013 dan maksimum sebesar 18,19 yaitu pada PT Matahari Department Store Tbk (LPFF) Tahun 2014 dengan standar deviasi sebesar 2,85. 
Jadi berdasarkan nilai rata-ratanya 1,51 menunjukkan bahwa besar beban hutang yang ditanggung perusahaan dibandingkan dengan aktivanya yaitu sebesar 1,51 dan ini relatif besar.

Untuk variabel ROA (PROFIT) rata-ratanya sebesar 0,01, nilai minimum -9,11 yaitu pada PT Global Teleshop Tbk (GLOB) Tahun 2015 dan maksimum sebesar 0,61 yaitu pada PT Matahari Department Store Tbk (LPFF) Tahun 2016 dengan standar deviasi sebesar 0,48. Jadi berdasarkan nilai rata-ratanya 0,01 menunjukkan bahwa rasio perbandingan laba bersih dengan total aset mengalami keuntungan 1\%. Artinya rasio ini termasuk rendah karena dibawah $20 \%$.

Nilai minimum untuk variabel luas pengungkapan manajemen kunci sebesar 1,00 yaitu pada PT. Plaza Indonesia Realty Tbk (PLIN) Tahun 2015 dan maksimum sebesar 4,00 yaitu pada PT. Telekomunikasi Indonesia Tbk (TLKM) Tahun 2015 dengan rata-ratanya sebesar 1,17 dengan standar deviasi sebesar 0,45 . Jadi berdasarkan nilai rata-rata sebesar 1,17 menunjukkan bahwa rata-rata perusahaan yang menjadi sampel pada penelitian ini perusahaan mengungkapkan total kompensasi masing-masing komisaris dan direktur antara skor 1 atau skor 2. Skor 1 diberikan apabila perusahaan hanya menyajikan total kompensasi tanpa keterangan kategori imbalan. Skor 2 diberikan apabila perusahaan mengungkapkan total kompensasi masing-masing komisaris dan direktur.

Tabel 3.

Frekuensi Kualitas Audit (KA)

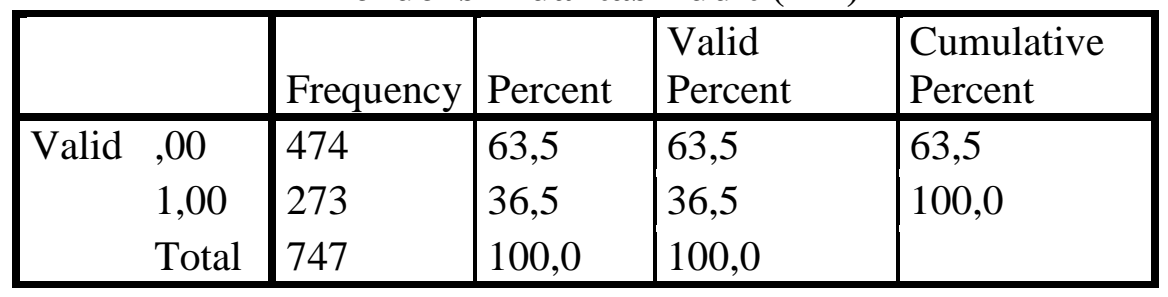

Berdasarkan pada tabel 3. diketahui bahwa variabel kualitas audit ada 474 perusahaan yang diaudit oleh KAP Non Big Four dan hanya 273 perusahaan diaudit oleh KAP Big Four. Artinya lebih mayoritas perusahaan pada penelitian ini diaudit oleh KAP Big Non Four.

Tabel 4.

Frekuensi Komite Remunerasi (KR)

\begin{tabular}{|c|c|c|c|c|c|}
\hline & & Frequency & Percent & $\begin{array}{l}\text { Valid } \\
\text { Percent }\end{array}$ & $\begin{array}{l}\text { Cumulative } \\
\text { Percent }\end{array}$ \\
\hline Valid & $\begin{array}{l}, 00 \\
1,00 \\
\text { Total }\end{array}$ & $\begin{array}{l}310 \\
437 \\
747\end{array}$ & $\begin{array}{l}41,5 \\
58,5 \\
100,0\end{array}$ & $\begin{array}{l}41,5 \\
58,5 \\
100,0\end{array}$ & $\begin{array}{l}11,5 \\
100,0\end{array}$ \\
\hline
\end{tabular}

Dari tabel diatas diketahui bahwa untuk variabel komite remunerasi (KR) ada 310 perusahaan yang tidak memiliki komite remunerasi dan 437 perusahaan yang memiliki komite remunerasi. Artinya mayoritas perusahaan pada penelitian ini memiliki komite remunerasi $(58.5 \%)$.

\section{Hasil Uji Hipotesis}

Tabel 4.9 menyajikan hasil analisis regresi pengaruh transparansi, Komite Audit, kepemilikan keluarga, Kualitas audit, dan komite remunerasi terhadap luas pengungkapan manajemen kunci. 
Tabel 5.

Hasil Analisis Regresi

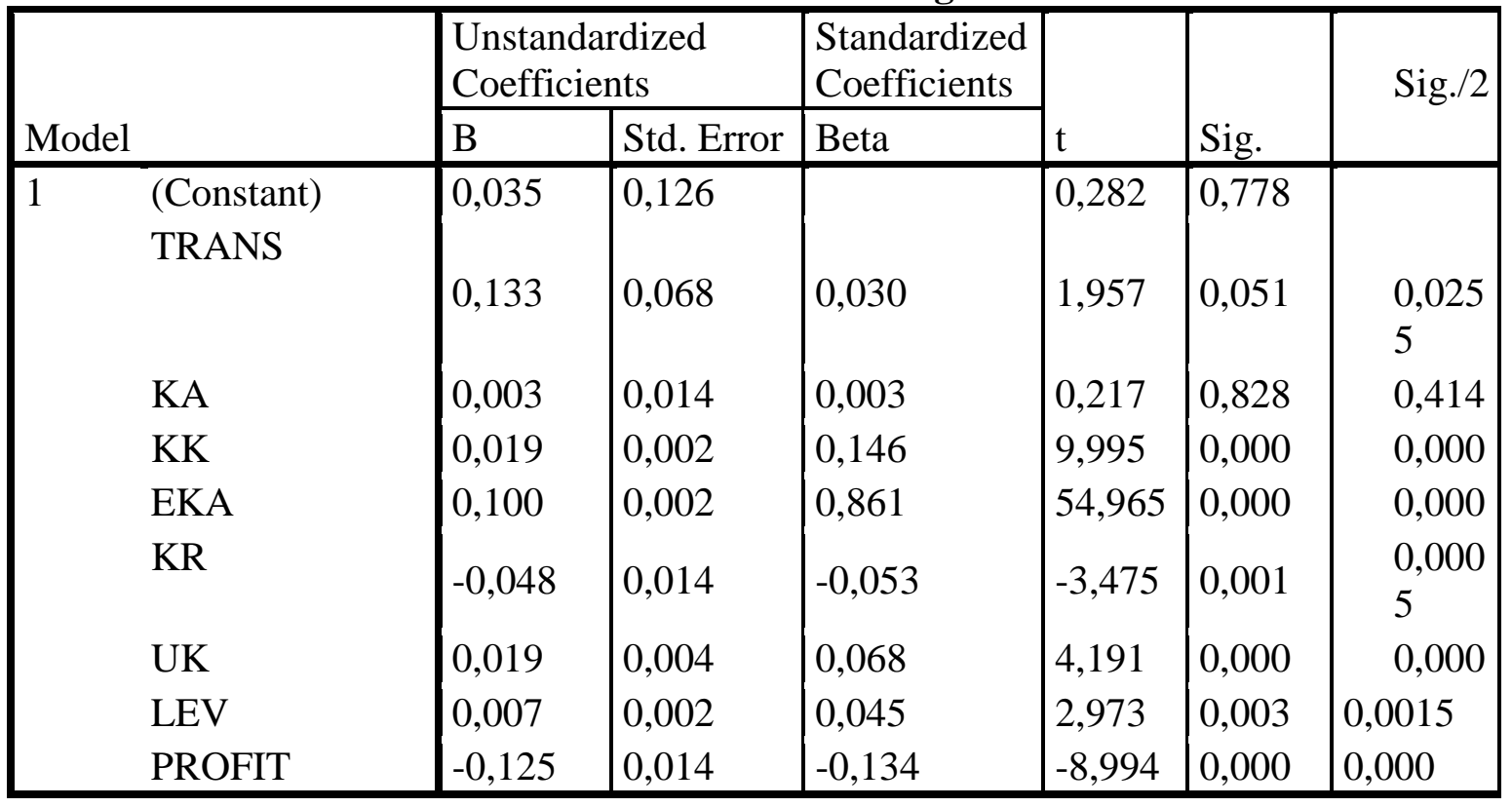

\section{Hipotesis Pertama}

Dari tabel 5. Dapat diketahui nilai signifikansi t untuk variabel transparansi tata kelola perusahaan sebesar $0,051 / 2=0,0255<0,05$ dengan nilai koefisien $+0,133$ sehingga artinya hipotesis pertama pada penelitian ini diterima. Jadi transparansi tata kelola perusahaan berpengaruh positif terhadap luas pengungkapan kompensasi manajemen kunci di laporan keuangan.

\section{Hipotesis Kedua}

Dari tabel 5. diketahui nilai signifikansi t untuk variabel kualitas audit sebesar $0,828 / 2=0,414>0,05$ artinya hipotesis kedua pada penelitian ini ditolak. Jadi kualitas audit tidak berpengaruh terhadap luas pengungkapan kompensasi manajemen kunci di laporan keuangan.

\section{Hipotesis Ketiga}

Dari tabel 5. diketahui nilai signifikansi t untuk variabel kepemilikan keluarga sebesar $0,000 / 2=0,000<0,05$ dengan nilai koefisien +0.019 sehingga artinya hipotesis ketiga pada penelitian ini diterima. Jadi kepemilikan keluarga berpengaruh positif terhadap luas pengungkapan kompensasi manajemen kunci di laporan keuangan.

\section{Hipotesis Keempat}

Dari tabel 5. diketahui nilai signifikansi t untuk variabel efektifitas pertemuan komite audit sebesar $0,000 / 2=0,000<0,05$ dengan nilai koefisien $+0,100$ sehingga artinya hipotesis keempat pada penelitian ini diterima. Jadi efektivitas komite auditberpengaruh positif terhadap luas pengungkapan kompensasi manajemen kunci di laporan keuangan. 


\section{Hipotesis Kelima}

Dari tabel 5. diketahui nilai signifikansi t untuk variabel komite remunerasi sebesar $0,001 / 2=0,0005<0,05$ dengan nilai koefisien $-0,048$ sehingga artinya hipotesis kelima pada penelitian ini ditolak karena berbeda arah. Jadi komite remunerasi berpengaruh negatif terhadap luas pengungkapan kompensasi manajemen kunci di laporan keuangan.

\section{Pembahasan}

Nilai signifikansi t untuk variabel transparansi tata kelola perusahaan dibawah 0,05 sehingga artinya hipotesis pertama pada penelitian ini diterima. Jadi Transparansi tata kelola perusahaan berpengaruh positif terhadap luas pengungkapan kompensasi manajemen kunci di Laporan Keuangan.

Corporate Governance atau tata kelola perusahaan merupakan struktur dan mekisme yang mengatur pengelolaan perusahaan sehingga menghasilkan nilai ekonomi jangka panjang yang berkesinambungan bagi para pemegang saham maupun pemangku kepentingan. Penerapan prinsip-prinsip tata kelola perusahaan yang baik dapat berkontribusi dalam peningkatan kinerja perusahaan.Perusahaan yang memiliki good corporate governance yang baik berarti kinerjanya semakin baik (Sari, 2013).

Corporate governance muncul karena terjadi pemisahan antara kepemilikan dengan pengendalian perusahaan, atau seringkali dikenal dengan istilah masalah keagenan. Permasalahan keagenan dalam hubungannya antara pemilik modal dengan manajer adalah bagaimana sulitnya pemilik dalam memastikan bahwa dana yang ditanamkan tidak diambil alih atau diinvestasikan pada proyek yang tidak menguntungkan sehingga tidak mendatangkan return. Corporate governance diperlukan untuk mengurangi permasalahan keagenan antara pemilik dan manajer (Conyon, 2011). Corporate Governance adalah rangkaian proses terstruktur yang digunakan untuk mengelola serta mengarahkan atau memimpin bisnis dan usahausaha korporasi dengan tujuan untuk meningkatkan nilai-nilai perusahaan serta kontinuitas usaha.

Salah satu aspek dalam GCG adalah terkait keterbukaan atau transparansi perusahaan. Dengan adanya keterbukaan informasi atas proses kerja yang berlangsung, para pemangku kepentingan akan terlayani dengan baik. Penerapan transparansi bisnis sebagai kunci tata kelola perusahaan. Menurut ASEAN Corporate Governance adalah hal yang penting sehingga (ACMF, 2017).

Apabila implementasi transparansi tata kelola perusahaan semakin tinggi maka semakin baik pula tingkat keterbukaan dari tata kelola perusahaan dan ini merupakan informasi pentingbagi para investor. Transparansi tata kelola perusahaan ini sangat berguna bagi investor untuk mengetahui supaya kompensasi dari manajemen kunci supaya memadai atau layak dan perusahaan dapat dikelola dengan baik. Jika manajemen kunci memperoleh kompensasi yang layak dan sesuai dengan sumber daya yang dimiliki oleh perusahaan seperti aset yang dimiliki perusahaan, laba yang diperoleh perusahaan, sehingga perusahaan akan tetap dapat membayar hutangnya dan dapat melakukan investasi. Dengan demikian investor akan tertarik menanamkan modal atau sahamnya pada perusahaan yang bersangkutan sehingga akan berdampak pada luas pengungkapan kompensasi manajemen kunci di Laporan Keuangan. Dengan demikian dapat dikatakan ada pengaruh positif antara transparansi tata kelola perusahaan terhadap luas pengungkapan kompensasi manajemen kunci di Laporan Keuangan.

Hasil penelitian ini konsisten dengan penelitian Conyon dan He (2011) yang menemukan hubungan positif antara tata kelola perusahaan terhadap luas pengungkapan kompensasi manajemen kunci di Laporan Keuangan. Dengan begitu, para pihak eksternal dapat menilai kinerja suatu perusahaan, salah satunya dengan melihat jumlah kompensasi manajemen kunci di Laporan Keuangan. 
Nilai signifikansi t untuk variabel kualitas audit diatas 0,05 artinya hipotesis kedua pada penelitian ini ditolak. Jadi kualitas audit tidak berpengaruh terhadap luas pengungkapan kompensasi manajemen kunci di Laporan Keuangan. Kualitas audit menurut DeAngelo (1981) adalah kemungkinan bahwa seorang auditor akan mampu untuk menemukan pelanggaran di dalam sistem akuntansi kliennya dan kemudian melaporkan pelanggaran tersebut. Para pengguna laporan keuangan berpendapat bahwa kualitas audit yang dimaksud jika auditor dapat memberikan jaminan bahwa tidak ada salah saji yang material (no material misstatements) atau kecurangan (fraud) dalam laporan keuangan audit.

Penelitian ini mendukung penelitian Hardiningsih (2010) yang menemukan bahwa kualitas audit tidak berpengaruh terhadap integritas laporan keuangan. Penelitian ini terdapat perusahaan-perusahaan yang tidak menggunakan KAP Big 4 tetap mengungkapkan kompensasi manajemen kunci secara luas. Tidak adanya peraturan yang mengharuskan melaporkan kompensasi manajemen kunci secara rinci atau luas, sehingga meskipun KAP yang mengaudit adalah KAP Big 4, namun KAP tidak bisa menekan perusahaan untuk melaporkan kompensasi manajemen kunci secara rinci di laporan keuangan. Ini yang menyebabkan tidak berpengaruhnya kualitas audit terhadap luas pengungkapan kompensasi manajemen kunci.

Nilai signifikansi t untuk variabel kepemilikan keluarga sebesar dibawah 0,05 dengan nilai koefisien regresi positif sehingga artinya hipotesis ketiga pada penelitian ini diterima. Jadi kepemilikan keluarga berpengaruh positif terhadap luas pengungkapan kompensasi manajemen kunci di Laporan Keuangan.

Semakin tinggi prosentase kepemilikan keluarga, menunjukkan bahwa pengawasan atau monitoring dari pihak keluarga semakin baik dan ketat. Supaya pihak luar atau investor mengetahui kondisi atau kinerja perusahaan tersebut maka dibutuhkan sinyal positif ke pasar. Semakin besar prosentase kepemilikan keluarga mengindikasikan semakin baik pula tingkat pengawasan sehingga pencapaian kinerja perusahaan semakin baik dan dengan kinerja yang semakin baik maka manajemen kunci akan menuntut kompensasi yang memadai. Supaya pihak investor (luar) mengetahui kondisi perusahaan tersebut, maka pihak manajemen perusahaan akan terdorong untuk melakukan pengungkapan lebih luas dalam laporan keuangan perusahaan, termasuk dalam pengungkapan kompensasi manajemen kunci di Laporan Keuangan untuk semakin meyakinkan investor untuk melakukan investasi di suatu perusahaan. Dengan demikian adanya pengaruh positif antara kepemilikan keluarga terhadap luas pengungkapan kompensasi manajemen kunci di laporan keuangan.

Hasil penelitian ini konsisten dengan Akmyga dan Mita (2015) yang menemukan bahwa kepemilikan keluarga berpengaruh positif terhadap luas pengungkapan kompensasi manajemen kunci di Laporan Keuangan.

Nilai signifikansi t untuk variabel efektifitas pertemuan komite audit dibawah 0,05 dengan nilai koefisien regresi positif sehingga artinya hipotesis keempat pada penelitian ini diterima. Jadi efektivitas komite auditberpengaruh positif terhadap luas pengungkapan kompensasi manajemen kunci di Laporan Keuangan.

Komite audit yang bertugas dengan efektif dapat mendorong internal control perusahaan menjadi lebih baik. Praktik internal control yang baik diharapkan dapat mendorong kepatuhan perusahaan untuk mematuhi standar akuntansi yang berlaku, salah satunya melalui pengungkapan kompensasi manajemen kunci di laporan keuangan (Wang, 2006). Efektifitas pertemuan komite audit diukur dengan jumlah rapat komite audit yang ada dalam sebuah perusahaan dalam setahun. Semakin efektif komite audit berarti dalam menjalankan tugasnya semakin baik karena semakin banyak diskusi dilakukan dalam rapat tersebut dan ini akan meningkatkan proses monitoring. Tugas atau fungsi dari komite audit sebagai wakil dari Dewan Komisaris dan pemegang saham adalah melakukan evaluasi dan penelaahan Laporan Keuangan Perseroan secara periodik berdasarkan peraturan dan prinsip-prinsip akuntansi yang berlaku, memberikan rekomendasi sehubungan dengan proses pengendalian internal. 
Hasil ini konsisten dengan penelitian yang dilakukan oleh Zhang et al. (2007) yang menemukan bahwa komite audit yang bertugas dengan efektif dapat mendorong internal control perusahaan menjadi lebih baik. Praktik internal control yang baik diharapkan dapat mendorong kepatuhan perusahaan untuk mematuhi standar akuntansi yang berlaku, salah satunya melalui pengungkapan kompensasi manajemen kunci di laporan keuangan. Hasil ini juga konsisten dengan penelitian yang dilakukan oleh Astasari dan Nugrahanti (2017) yang menunjukkan bahwa efektivitas komite audit berpengaruh positif terhadap luas pengungkapan kompensasi manajemen kunci.

Nilai signifikansi t untuk variabel komite remunerasi dibawah 0,05 dengan nilai koefisien regresi positif sehingga artinya hipotesis kelima pada penelitian ini ditolak karena berbeda arah. Jadi komite remunerasi berpengaruh negatif terhadap luas pengungkapan kompensasi manajemen kunci di Laporan Keuangan.

Alasan ditolaknya hipotesis ini adalah karena Komite remunerasi memiliki aturan yang harus ditaati seperti Peraturan OJK No 55 / POJK.03/ 2016 , tugas dari komite remunerasi terkait dengan kebijakan remunerasi adalah melakukan evaluasi terhadap kebijakan remunerasi yang didasarkan atas kinerja, risiko, kewajaran dengan peer group, sasaran, menyampaikan hasil evaluasi dan rekomendasi kepada Dewan Komisaris mengenai: kebijakan remunerasi bagi Direksi dan Dewan Komisaris untuk disampaikan kepada RUPS; dan menyusun dan memberikan rekomendasi mengenai sistem serta prosedur pemilihan dan/atau penggantian anggota Direksi dan anggota Dewan Komisaris kepada Dewan Komisaris untuk disampaikan kepada RUPS, jadi dengan adanya aturan yang semakin ketat terhadap evaluasi kebijakan remunerasi maka perusaahaan akan menjadi takut dalam mengungkapkan kompensasi manajemen kunci sehingga akan menurunkan luas pengungkapan kompensasi manajemen kunci. Hasil ini tidak konsisten dengan penelitian yang dilakukan Liu (2008) bahwa komite remunerasi audit berpengaruh positif terhadap luas pengungkapan kompensasi manajemen kunci.

\section{KESIMPULAN dan SARAN}

\section{Kesimpulan}

Dari hasil penelitian yang telah dilakukan, maka kesimpulan yang dapat diambil :

1. Transparansi tata kelola perusahaan berpengaruh positif terhadap luas pengungkapan kompensasi manajemen kunci di Laporan Keuangan. Jadi hipotesis pertama diterima.

2. Kualitas audit tidak berpengaruh terhadap luas pengungkapan kompensasi manajemen kunci di Laporan Keuangan. Jadi hipotesis kedua ditolak.

3. Kepemilikan keluarga berpengaruh positif terhadap luas pengungkapan kompensasi manajemen kunci di Laporan Keuangan. Jadi hipotesis ketiga diterima

4. Efektivitas komite auditberpengaruh positif terhadap luas pengungkapan kompensasi manajemen kunci di Laporan Keuangan. Jadi hipotesis keempat diterima.

5. Komite remunerasi berpengaruh negatif terhadap luas pengungkapan kompensasi manajemen kunci di Laporan Keuangan. Jadi hipotesis kelima ditolak.

\section{Saran}

Sedangkan saran yang dapat dikemukakan pada penelitian ini adalah sebagai berikut:

Pada penelitian mendatang dengan topik serupa dapat ditambahkan variabel lain misalnya dewan komisaris independen yang mempengaruhi luas pengungkapan kompensasi manajemen kunci di Laporan Keuangan. Dewan komisaris independen memiliki fungsi mengawasi perusahaan karena dewan komisaris independen melaksanakan fungsi pengawasannya maka dia akan mendorong perusahaan akan lebih transparan dan lebih banyak mengungkapkan informasi terutama mengungkapkan luas kompensasi manajemen 
kunci, sehingga investor dapat mengetahui apakah gaji yang diberikan kepada manajer sudah sesuai dengan pendapatan perusahaan atau belum, jangan sampai pendapatan perusahaan kecil tetapi manajer digaji dengan jumlah yang besar. Jadi dengan adanya dewan komisaris independen, manajer tidak berani bermain-main dalam memberikan kompensasi pada dirinya sendiri dan dapat mendorong luas pengungkapan kompensasi manajemen kunci. Jadi dewan komisaris berpengaruh terhadap luas pengungkapan kompensasi manajemen kunci (Conyon dan He, 2011).

\section{DAFTAR PUSTAKA}

Akmyga, S.F., dan M. A. Farah. 2015.Pengaruh Struktur Corporate Governance Dan Kualitas Audit Terhadap Luas Pengungkapan Kompensasi Manajemen Kunci Di Laporan Keuangan. Jurnal Akuntansi dan Keuangan Indonesia.

Allegrini, M., and G. Greco. 2011. Corporate Boards, Audit Committees and Voluntary. Disclosure: Evidence From Italian Listed Companies. Journal Management.

Ananda, R. R. 2015. Pengaruh Kepemilikan Keluarga, Kepemilikan Manajerial, Dewan Komisaris, Komite Audit Dan Auditor Eksternal Terhadap Luasnya Pengungkapan Di Laporan Tahunan (Studi Empiris Pada Perusahaan Manufaktur Yang Terdaftar di Bursa Efek Indonesia Tahun 2012-2013 . Jom FEKON.

Claessens, S., S. Djankov, and L. H. Lang. 2000. The separation of ownership and control in East Asian Corporations. Journal of Financial Economics, 58(1- 2), 81-112.

Conyon, M.J. and L. He. 2011. Executive Compensation and Corporate Governance in China. Institute for Compensation Studies.

Dalton et al, 2011. The Fundamental Agency Problem and Its Mitigation. https://www.researchgate.net/publication/233456592_1The_Fundamental_Agency_Pr oblem_and_Its_Mitigation

DeAngelo, L.E. 1981. Auditor Size and Auditor Quality. Journal of Accounting and Economics, 3: 183-199.

Faccio, M.; L.H. Lang; and L. Young. 2001. Dividend and Expropriation. American Economic Review 91(54-78)

Ghozali, I. 2016. Analisis Multivariate dengan Program SPSS. Semarang: Undip.

Hardikasari, E. 2011. Pengaruh Penerapan Corporate Governanace Terhadap Kinerja Keuangan Pada Industri Perbankan yang Terdaftar di BEI Tahun 2006-2008. Jurnal Universitas Dipenogoro.

La Porta, R., Lopez-de-Silanes, F. and A. Shleifer. 1998. Corporate Ownership Around the World. Working Paper Series. 
Jensen, M. C. and W. H. Meckling. 1976. Theory of the Firm: Managerial Behavior, Agency Costs and Ownership Structure. Journal of Financial Economics, 3 (4), 305-360.

Mareysa, F. 2019. Pengaruh Kepemilikan Saham Institusional, Kualitas Audit, Frekuensi Pertemuan Komite Audit Dan Komite Remunerasi Terhadap Luas Pengungkapan Kompensasi Manajemen Kunci di Laporan Keuangan. Skripsi. Universitas Katolik Soegijapranata, Semarang.

Nuryaman. 2009. Pengaruh Konsentrasi Kepemilikan, Ukuran Perusahaan, Dan Mekanisme Corporate Governance Terhadap Pengungkapan Sukarela. Jumal Akuntansi dan Keuangan Indonesia 6 (1).

Oktamawati, M. 2016. Pengaruh Karakter Eksekutif, Komite Audit, Ukuran perusahaan, Leverage, Pertumbuhan Penjualan, dan Profitabilitas Terhadap Tax Avoidance. Skripsi. Program S1 Fakultas Ekonomi dan Bisnis Universitas Katolik Soegijapranata Semarang.

Omar, B. and J. Simon. 2011. Corporate Agregate Disclosure Practices in Jordan. Advances in Accounting, incorporating Advances in International Accounting, 27 (1), 166-186.

Putri. 2012. Pengaruh Kualitas Audit, Likuiditas, Profitabilitas, dan Auditor Changes terhadap Opini Audit Going Concern pada Perusahaan Manufaktur dan Non Manufaktur di Bursa Efek Indonesia Tahun 2007. Skripsi Tidak Dipublikasikan. Fakultas Ekonomi Universitas Sebelas Maret Surakarta.

Shleifer, A dan R.W. Vishny. 2012. A Survey of Corporate Governance. Journal of Finance. 52 (2), 737-783.

Simanjuntak. 2008. Pengaruh Time Budget Pressure Dan Resiko Kesalahan Terhadap Penurunan Kualitas Audit (Reduced Audit Qaulity). Skripsi Tidak Dipublikasikan. Undip, Semarang.

Suherman, M. 2019. Pengaruh Tata Kelola Perusahaan, Kualitas Audit, Leverage dan Profitabilitas Terhadap Luas Pengungkapan Kompensasi Manajemen Kunci di Laporan Keuangan. Skripsi Tidak Dipublikasikan. Semarang: Universitas Katolik Soegijapranata.

Suaryana, A. 2005. Pengaruh Komite Audit terhadap Kualitas Laba. Simposium Nasional Akuntansi VII.Solo.

Wooten, T.G. 2003. It is Impossible to Know The Number of Poor-Quality Audits that simply go undetected and unpublicized. The CPA Journal. Januari :48-51.

Utama, M. 2004. Komite Audit, Good Corporate Governance dan Pengungkapan Informasi. Jurnal Akuntansi dan Keuangan Indonesia, 1 (1), 61-79.

Zhang, Y., J. Zhou, and N. Zhou. 2007. Audit Committee Quality, Auditor Indepence, and Internal Control Weaknesses. Journal of Accounting and Public Policy, 26 (3), 300327. 